Canadian Journal of Family and Youth, 6(1), 2014, pp 205

ISSN 1718-9748 (c) University of Alberta

http://ejournals.library.ualberta.ca/index/php/cjfy

\title{
Raining on Babies
}

Terry Trowbridge ${ }^{1}$

Some babies are sitting together

in those things that are Hybrids

between car seats and picnic baskets.

When the rain comes down they stop

whatever it is they are doing

and with complete silence they look at their hands.

Probably this is intense concentration.

If I was supposed to teach them to meditate

I would put them in the rain.

If I was supposed to teach them to be artists

I would put them in the rain

because that was an all-encompassing look

that they gave to their fingers and the sensation of sudden

polka dotted cold.

\footnotetext{
${ }^{1}$ Terry Trowbridge's essays have been published in Rampike (2010) and Ariel (2010). He has co-authored literary criticism about bpNichol and cryptography in conference proceedings of the IEEE (2009, 2011), the ACM (2012) and also in Rampike (2012). His poetry has appeared in various venues, most recently dead (g)end(er) magazine (2011), Carousel (2013) and two chapbooks from Grey Borders Press in Niagara Falls, Slimy Bugs (2007) and That's Why They Shit So Much: Self-Help for Living with Passive-Aggressive Cats (2011). Terry is a PhD candidate in Socio-Legal Studies at York University.
} 